夏季の大阪湾に於ける珪藻群集の遷移と増殖の模式的表現(第 3 報 $)^{*}$

塩素量分布との関係に基く理藻増殖の模式的表現及び結論

上野 福 三**

\title{
The Variation of Diatom Communities and the Schematic Explanation of their Increase in Osaka Bay in Summer-III
}

\author{
Schematic Explanation of Increase of Diatoms in Relation \\ to the Distribution of Chlorinity
}

\author{
Fukuzo UYENO
}

\begin{abstract}
The author made a schematic explanation of increase of diatoms in relation to chlorinity in the productive zone of various communities in Osaka Bay in summer, as the distributions of communities have a close relation to the surface distribution of chlorinity.

2. The schema coincides with the present state in substance, especially in Skeletonemaand Nitzschia-Leptocylindrus-Thalassionema communities. However, some consideration on the effect of temperature may be needed for the case of Chaetoceros- and Lauderia-GuinardiaThalassiosira communities.

3. External factors by which these schematic distributions are destroyed are thought to be as follows :

(i) Circular current: In the case of decaying communities, the productive zone tends to move more eastward from its optimum region than in the case of normal community.

(ii) Difference of the speed between the decrease of chlorinity and the increase of

diatoms: In the case when chlorinity decreases rapidly and excessively, diatoms do not increases correspondingly, and the increase is late behind the decrease of chlorinity.

4. It is concluded that the quantity of diatoms may be expressed as a function of temperature and chlorinity in Osaka Bay.
\end{abstract}

1. 緒

前 2 報で夏季の:大阪湾に於ける珪藻群集の細胞 数の増減と分布域が湾の水温と塩素量, 殊に塩素 量の水平分布の傾度と密接な関係のあることを明 かにした。本報では結論として各群集は塩素量に よつて現わされる海況とどの様に関聯して分布す るか，又塩素量以外の要因にどの様に影響される かについて，模式的表現を用いて述べる．群集は 前 2 報に用いた次の 5 種について取扱つた. 1 .

* 1957 年 2 月 11 日受理, 本研究は交部省科学試铪研 究費によるところが大きい。

** 神戸海洋気象台, Kobe Marine Observatory, Kobe.
Skeletonema costatum の群集 (Sk 群集と略す), 2. Chaetoceros 属を主とする群集 (Ch 群集と 略す), 3. Nitzschia 属, Leptocylindrus danicus, Thalassionema nitzschioides を主とする群 集 (N-L-T 群集と略す)，4. Lauderia borealis, Guinardia flaccida, Thalassiosira nordenskioldii を主とする群集 (L-G-T 群集と略す)， 5. Coscinodiscus 属, Rhizosolenia 属を主とする群 集 (Cos 群集と略す).

\section{2. 分布の模式的表現}

策 2 報に於いて増殖の中心域の $\mathrm{Cl}$ 值の相異に 
つき群集毎に述べた．これを一括して現わすと第 1 表のよ5になる. 第 1 表に基き, 種々の $\mathrm{Cl}$ 分布 の場合に珪藻分布の傾向がどの様に変化するかを 模式的に示せば，第1３図の様になる. 先づ第 1 図に於いては $\mathrm{Cl}$ 值が全群集の増殖に不適と思 われる地域で示す低い值から，大阪湾で見られる 最高值まで一定の勾配で分布した場合について, 各種の群集の分布傾向を，それぞれの濃密域の $\mathrm{Cl}$ 值域（第 1 表）の位置を中心に示したものである. なお同図では煩雑を避けるため，出現時期は異る が塩素量分布との関係は N-L-T 群集と大差のな
い L-G-T 群集は省略した. 珪藻の量は採集方法 の関係から推定が困難なので, 別の機会に報告す ることにし，ここでは量の変化傾向のみを示して 絶対量は示さなかつた。この䉕 1 図によつて各群 集が濃密となる地域に於ける塩素量值の相異を明 瞭に知ることが出来る. 観測は湾奥から湾口まで に数ケ所の地点を設定して行い, 連続的に各.要素 の変動は記録しない、今同図の場合について最上 部に示した様な等間隔の 5 地点を選んだとする と, Ch 群集及び N-L-T 群集中の Nitzschia delicatissima 以外の各種は St. 1 で最大を示すの

Table 1. Chlorinities $(\% 0)$ in the productive region of the communities.

\begin{tabular}{l|c|c|c}
\multicolumn{1}{c|}{ Community } & Lower limit & Optimum & Upper limit \\
\hline Skeletonema costatum & $9.0-10.0$ & $14.0-15.0$ & $16.0-17.0$ \\
\hline Chaetoceros affinis & $10.0-12.0$ & $16.0-16.5$ & 16.5 \\
Chaetoceros spp. & 16.0 & $16.5-17.0$ & 17.0 \\
\hline Nitzschia delicatissima & $10.0-12.0$ & $15.0-16.0$ & 16.0 \\
Nitzschia seriata, Leptocylindrus danicus & $13.0-14.0$ & $15.0-16.0$ & 16.0 \\
Thalassionema nitzschioides & 15.0 & $15.0-16.0$ & 16.0 \\
Lauderia borealis & 15.0 & $16.0-17.0$ & 17.0 \\
Guinardia flaccida & 16.0 & 17.0 & 17.0 \\
Thalassiosira nordenskiöldii & 14.5 & 16.5 & 17.0 \\
\hline Coscinodiscus spp. & 17.0 & $?$ & $?$
\end{tabular}

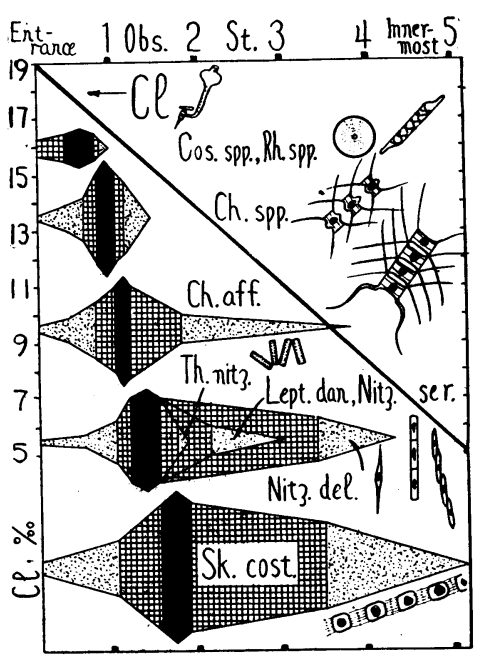

Fig. 1.

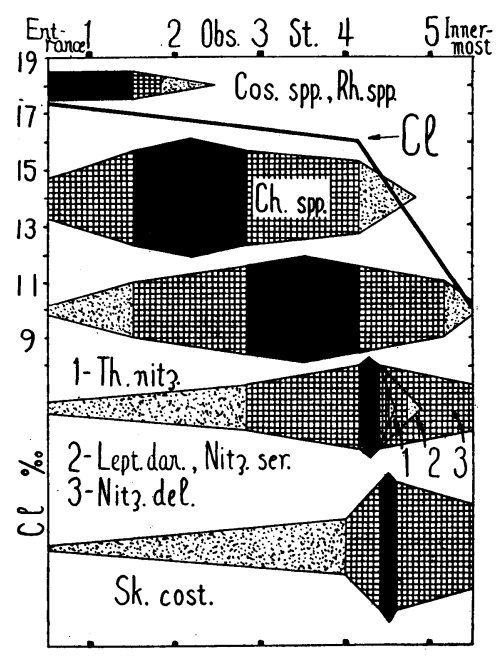

Fig. 2.

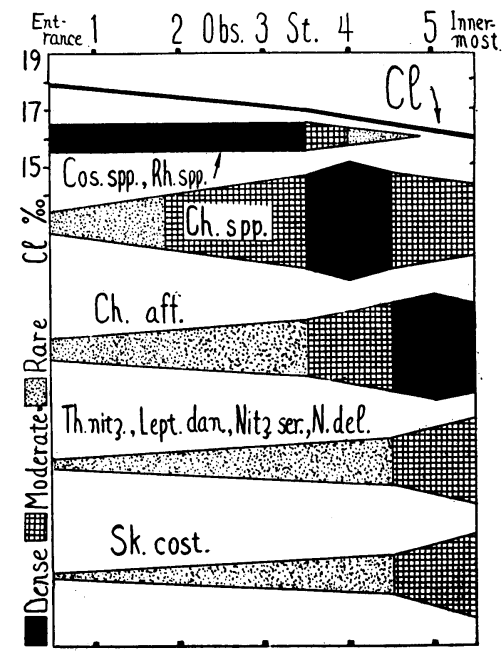

Fig. 3.

Figs. 1 3. Three schematic explanations of distribution of diatom communities according to $\mathrm{Cl}$ distribution. 
みならず，他の地点では殆ど出現しなくなる。こ れに対し $N$. delicatissima は St. 1〜3 に多く, Sk 群集は St. 2 で最大を示して St. 4 まで多量 に分布することになる. 1952 年 7 月の場合は同 図の様な分布様式を示している.

次に笛 2 図では湾口から湾奥までの $\mathrm{Cl}$ 分布の 傾度を第 1 図より緩やかにして示した．同図では $\mathrm{Cl}$ を一様に変化させず，湾口から湾奥近くまで 16〜 17\% \% 間の緩やかな傾度で分布し，湾奥部で 急激に $10 \%$ まで下降した場合について示した。 16〜 17\% の傾度が緩やかであるとCh 群集の分 布域が非常に広くなり, 且 Ch. affinis が他の種 より湾奥側に分布する。 また N-L-T 群集は主と して湾奥に限られる..この様な分布は 1954 年 7 月の状況と殆ど一致する.

また第 3 図では湾奥の $\mathrm{Cl}$ 低下の殆どない 8,9 月頃の状況に近い場合として, 湾口の $18 \%$ 多から湾 奥の $16 \%$ まで略々平均して緩やかに変化した場 合を示した.この場合は $\operatorname{Cos}$ 群集が最も広く分 布し，Ch. spp. がこれに次いでいる. しかし乍 ら Cos 群集以外は湾奥附近でいちじるしく多く なつている. 又 N-L-T 及び Sk 両群集は湾奥に 限られ，量は少なくなる。この様な分布の実際例 は多く大阪湾では最も普通の場合と考兄られる.

この例の他, 実際の $\mathrm{Cl}$ 分布は降水量や潮流等 の多くの要因で様々に変化するから, 他にも多く の場合があると思われる. しかし 1952〜1955 の 4年間に見られた主なものとしては上記 3 例の他, 第 2 例より稍々低い $\mathrm{Cl}$ 值の部分で傾度が緩やか となつたため, N-L-T 群集の所属諸種の分布が分 れた場合が 1953 年 7 月, 1955 年 10 月等に見ら れる.これも全く同一の原理によつて分布図を作 れるので四は略した．この 4 例が主なるのである が，この他の $\mathrm{Cl}$ 分布の場合も同一原理で概ね解 決されると思われる.

\section{3. 分布模式を崩す外的要因}

以上に述べたものは全く基本的なもので，実際 にはこれを修正せねばならぬ要因がいくつか介入 して来る.

先づ $\mathrm{Cl}$ の地理的分布差が当然問題になる. 第 1 報の海況の項で述べたように, 湾の地形, 深度
に上る潮流分布の不均一は当然 $\mathrm{Cl}$ 分布にも現わ れる.一般に東部は西部に比し $\mathrm{Cl}$ 量が低く, 水 平傾度も急である. 従つてこの様な $\mathrm{Cl}$ の地理的 分布差に基いて湾の珪藻分布も変り，一般には東 部に多く，且分布が複雑になる．また急激な出水 の場合は湾の主軸上の表層を低鹹水が進出して湾 の中央部に残留し, 中央部で増殖することもある.

次に環流の影響で衰退期の群集の分布域が $\mathrm{Cl}$ 分布より東にずれることがある. この問題は策 2 報に詳述したので省略する.

又 $\mathrm{Cl}$ の変化と珪藻の増殖速度の差が甚しくな つた場合におこる問題がある。第 1〜3 の分布模 式に於いて, $\mathrm{Cl}$ 值が各群集の増殖域の $\mathrm{Cl}$ 值より 低くなると珪藻量も少くなつている。しかし乍ら 実際には同図に見られる増殖域の $\mathrm{Cl}$ 值以下の地 域でも非常に多い場合が㕍々見られる.この様な ことは湾奥の $\mathrm{Cl}$ 低下が急激で, 且低下域が中央 部附近まで進出した場合に現われる. 出水によつ て珪藻増殖に適当な海況を形成しても，珪藻の細 胞数の増加が観測されるまでには一定の時間を要 する. 従つて出水による $\mathrm{Cl}$ の低下が急激で且長 時間継続した場合には, 珪藻量の増加が観測され た時には, 既にその地点の $\mathrm{Cl}$ 值は増殖をおこす のに適当な $\mathrm{Cl}$ 值より低くなつている.この様な 例は 7 月に多い。

\section{4. 出現時期と量の問題及び異常現象と思われる 例外}

Sk 及び N-L-T 群集は略々全期間に互り出現 するので時期の問題はない.この両群集は殆ど基 本形式に則ることになる.これに対し第1報で述べ た様に Ch 群集の細胞数は水温の影響を考虑に入 れる必要がある. この外 L-G-T 群集は Ch 群集 が減少すると増加する傾向があるので, Ch 群集 の変動を考慮せねね゙ならない。

上記の塩素量分布との関係に基く分布模式では 説明出来ない場合が 1 例ある. それは 1953 年 8 月の場合である.この時の分布は各群集共湾の中 央稍々北寄りの地点に多いが， $\mathrm{Cl}$ 分布は全く無 関係である.この原因についてはょく分らない． 同観測時は他の 3 年に比し水温は異常に高く, 底 層の溶在酸素量は著しく低い（神戸海洋気象台海 
洋課 1952,1953$)^{1}$ 。 これらのことが值接的か閒接 的に影響したのかとも思われる:

\section{5. 結 論}

以上に述べた樣に夏季の大阪湾の珪藻増殖は概 坟量量の水平分布に対応して量及び分布域が定 まり, Ch, L-G-T 群集については水温, その他で の考虑を加えればよいことが結論される. 従つて 珪藻増殖の年による変動は年による $\mathrm{Cl}$ 分布の変 動, 即ち降水の変動が大きく影響することになる.

更にこれを云い換えれば，一般に拄藻量は種々 の要因によつて決定されるが，大略的には珪藻量 永温と塩素量の函数として表示し得ることが予 测される. 而して Sk 群集や N-L-T 群集では Ch 群集に比し水温の影響は少ないと思われる. 従つて水温, 塩素量以外の要因が強く働くのは例 外的な場合であろう。

珪藻量の制限要因としては一般に日射，栄養塩 量等が上げられている. 夏季の大阪湾の珪藻量が 水温,塩素量に対応することは, かならずしも直接 的に水温及び塩素量が珪藻量の制限要因であると いうことは意味しない，栄養塩の何かが制限要因 であつても，その量が水温及び塩素量によつて表 示される海況と並行的に変化するものであれば, 間接的に水温及び塩素量と珪藻量の間に一定の関 係が現われる. 又松江 $(1954)^{2)}$ は Skeletonema costatum の培養に於いて, 増殖に好適な塩分值 のあることを述べているので水温又は塩素量が直 接的制限要因であるとも想像される.この間題に ついては全く判らない. 今後研究さるべきものと 思われる.

次に興味あることは，実際に湾内で屢々観測さ れる $\mathrm{Cl}$ 值の変動範囲と, 各珪集の濃密部の見出 された地域の $\mathrm{Cl}$ 值の範囲との関係である. 第.1 図及び第 1 表に示した各群集の増殖域の $\mathrm{Cl}$ 值は 大凡 15〜17\% の の範囲内に多少のずれをもつて配 列される: 一つ一つの群集の占める $\mathrm{Cl}$ 量の範 囲は非常に狹いが，下限の Sk 群集の夕は他に比 し広くなつている. 一方大阪湾内の $\mathrm{Cl}$ 值は 4 年 間に $15 \%$ ○墸しく低い值を示した地点がある がこの栐に低い值が広い地域を占めることは稀で 昰る。殊に Sk 群集の増殖域の Cl 值は, 地理的
には湾奥の河口附近の水平傾度の急な部分に相 当し，広範囲を占める機会は少ない: 又 Chaetoceros 属等の様に比較的狹い $\mathrm{Cl}$ 值の増殖域を持 つ群集の増殖域 $\mathrm{Cl}$ 值は湾の中央附近に現われる ことが多く，且傾度が緩やかであるため地理的に は広範囲を占める機会が多い。この様に各群集の 増殖域の $\mathrm{Cl}$ 值の狹広は, 湾内の $\mathrm{Cl}$ 分布によつ て相殺されて, 各群集が地理的には比較的平均し て分布することが多く, 特定の種が広い地域を占 めることは極めて稀であると云える．このことは 宮地，森 $\left.(1955)^{3}\right)$ が個体間の棲息範囲について用 いている「第 1 種のすみわけ」と似た形態が群集 間にも現われていることを示す様に思われる.

\section{6. 要 約}

1. 大阪湾の夏季増殖に拈ける珪藻の分布域と 出現量は $\mathrm{Cl}$ 量の水平分布と密接に関係するので, 各群集の増殖域の $\mathrm{Cl}$ 值に基き分布模式を作つた.

2. この分布模式は増減傾向が水温の変化と並 行的関係にある Chaetoceros 群集では水温の考 慮を入れる必要がある. 又 Lauderia-GuinardiaThalassiosira 群集は, Ch 群集の増減を考慮す る必要がある。

3. 分布模式を崩す外的要因に次のものがある.

（i ）環流：群集の衰退期には分布域が $\mathrm{Cl}$ 分布より東にずれる.

(ii) $\mathrm{Cl}$ 低下と珪藻増殖の速度差: $\mathrm{Cl}$ 低下 が急速な場合, 珠藻はこれと対応して増加するこ とが出来ず, 増殖が遅れる. 従つて出水時の増殖 域の $\mathrm{Cl}$ 值は一般に低目になる.

4. 結論として各群集の珪藻量は主に水温と塩 素量の函数として現わし得ることが予測される.

\section{文献}

(1) 神戸海洋気象台海洋課, 1952, 1953 : “大阪湾定期海洋観測報告 (1952 年 8,9 10 月), 同 (1953 年 8 月) ”, 神戸海洋時報, 2 , 3, $10 ; 2,4,9$.

(2) 松江吉行, 1954 :

“海産浮游珪藻 ‘スケレトネマ’ [Skeletonema costatum (Grev.) Cleve] の培養（培 養の基本問題と繁殖生理に関する培養実 験) ”, 水産学の概観, 日本学術振興会, 東京.

(3) - 宮地伝三郎・森主一, 1953 :

“動物の生態”, 岩波書店, 東京. 